\title{
KORELASI KEHADIRAN DAN PENYELESAIAN TUGAS TERHADAP NILAI AKHIR MAHASISWA PENDIDIKAN GEOGRAFI IKIP PGRI PONTIANAK TAHUN 2017
}

\author{
Eviliyanto $^{1}$, Endah Evy Nurekawati ${ }^{2}$ \\ ${ }^{1}$ Pendidikan Geografi IKIP PGRI Pontianak. \\ ( $\square$ ) Eviliyanto@yahoo.co.id \\ ${ }^{2}$ Pendidikan Geografi IKIP PGRI Pontianak. \\ ( $\square$ ) evy_nurekawati@yahoo.co.id
}

\begin{abstract}
ABSTRAK
Tujuan penelitian ini adalah: 1) untuk mengetahui kehadiran mahasiswa Pendidikan Geografi pada mata kuliah kartografi/praktek pemetaan semester VI tahun ajaran 2016/2017, 2) untuk mengetahui penyelesaian tugas mahasiswa Pendidikan Geografi pada mata kuliah kartografi/praktek pemetaan semester VI tahun ajaran 2016/2017, 3) untuk mengetahui hubungan kehadiran dengan nilai akhir evaluasi pembelajaran mahasiswa Pendidikan Geografi pada mata kuliah kartografi/praktek pemetaan semester VI tahun ajaran 2016/2017, 4) untuk mengetahui hubungan penyelesaian tugas dengan nilai akhir evaluasi pembelajaran mahasiswa semester VI tahun ajaran 2016/2017. Metode penelitian dalam upaya memperoleh data dengan menggunakan metode deskriptif. Subyek penelitian adalah mahasiswa kelas A. Pagi semester VI Prodi Pendidikan Geografi yang mengambil mata kuliah kartografi/praktek pemetaan. Teknik pengumpulan data yang digunakan untuk menjawab permasalahan pertama dengan observasi langsung melalui pengamatan terhadap mahasiswa, sedangkan permasalahan kedua, ketiga dan keempat dengan teknik dokumentasi melalui rekapitulasi laporan dan hasilnya berupa nilai akhir. Hasil penelitian menunjukkan bahwa: 1) kehadiran mahasiswa Pendidikan Geografi pada mata kuliah kartografi/praktek pemetaan semester VI kelas A.Pagi tahun ajaran 2016/2017 termasuk kategori sangat baik, 2) penyelesaian tugas/nilai akhirmahasiswa Pendidikan Geografi pada mata kuliah kartografi/praktek pemetaan semester VI kelas A.Pagi tahun ajaran 2016/2017 termasuk kategori cukup baik, 3) korelasi kehadiran dengan penyelesaian tugas/nilai akhir mahasiswa Pendidikan Geografi pada mata kuliah kartografi/praktek pemetaan semester VI kelas A.Pagi tahun ajaran 2016/2017 termasuk lemah, 4) korelasi penyelesaian tugas dengan nilai akhir mahasiswa Pendidikan Geografi pada mata kuliah kartogrfi/praktek pemetaan semester VI kelas A.Pagi tahun ajaran 2016/2017 termasuk sangat tinggi.
\end{abstract}

Kata kunci: kehadiran, tugas, dan nilai

\section{PENDAHULUAN}

Tujuan pendidikan pada dasarnya mengantarkan para siswa menuju pada perubahanperubahan tingkah laku baik intelektual, moral maupun sosial agar dapat hidup mandiri sebagai individu dan makhluk sosial. Dalam mencapai tujuan tersebut siswa berinteraksi dengan lingkungan belajar yang diatur guru melalui proses pengajaran (Sudjana dan Rivai, 2013: 1).

Menurut Nugroho (2013: 3) lingkungan belajar adalah suatu kesatuan sistem yang terorganisir untuk mencapai tujuan yang telah dirumuskan, sehingga setiap peristiwa pembelajaran mempunyai pola dan tujuan tertentu. Berdasarkan pengertian tersebut lingkungan belajar menunjuk pada pengertian pengajaran sebagai suatu sistem, yaitu suatu kesatuan yang terorganisir. Artinya pengajaran itu terdiri atas berbagai komponen (tujuan, materi, metode, dan evaluasi) yang saling berhubungan dan saling mempengaruhi satu dengan yang lain dalam rangka mencapai tujuan pembelajaran yang telah dirumuskan (Suharyono, 1991: 5). Tidak 
terkecuali dalam pembelajaran geografi yang tidak hanya terbatas sebagai suatu deskripsi tentang bumi atau permukaan bumi, melainkan meliputi juga analisis hubungan antara aspek fisik dengan aspek manusia. Dengan demikian perhatian dan analisis pada studi geografi tidak hanya ditujukan kepada alam lingkungan, melainkan juga berkenaan dengan umat manusia serta hubungan diantara keduanya, sekaligus mengkaji faktor alam dan faktor manusia yang membentuk integrasi keruangan diwilayah yang bersangkutan (Sumarmi, 2012: 7).

Tidak hanya dijenjang pendidikan pertama dan menengah, tetapi jenjang perguruan tinggi seorang pendidik dalam hal ini dosen pengampu mata kuliah berkewajiban mempersiapkan perangkat pembelajaran. Melalui perangkat yang telah dipersiapkan, seorang dosen harus mampu mengembangkan materi sesuai dengan tujuan yang telah ditentukan agar mahasiswa dapat memperoleh informasi yang komprehensif. Khususnya pada mata kuliah kartografi/praktek pemetaan yang mengkaji unsur-unsur, luas, jarak, arah, bahkan sampai pada penyusunan peta tematik.

Mata kuliah ini dirancang dan diberikan dalam enam empat belas kali pertemuan efektif kepada mahasiswa. Harapannya melalui proses perkuliahan tersebut dapat memberikan pemahaman kaitannya dengan pemahaman mengenai komponen dan tahapan penyusunan peta tematik sesuai dengan data yang diperoleh. Dalam proses perkuliahan penyampaian materi dengan menggunakan metode ceramah dengan berbantu spidol tiga warna. Alasan penggunaan metode ceramah berbantu spidol tiga warna karena masih adanya relevansi dengan materi yang disampaikan (teori, komponen-komponen peta dan tahapan penyusunan peta tematik).

Namun, hasil pengamatan yang diperoleh dari proses perkuliahan menunjukkan bahwasanya mahasiswa beranggapan dengan kuantitas kehadiran mampu memperoleh hasil evaluasi yang baik. Sebagai contoh kasus yang masih terjadi sampai saat ini mengenai mahasiswa melakukan konfirmasi nilai yang tidak sesuai dengan harapan mereka. Tanpa disadari hal tersebut menjadi kebiasaan/budaya kurang baik yang ditularkan secara tidak langsung terhadap angkatan-angkatan berikutnya. Sudah barang tentu seorang dosen pengampu mata kuliah dalam proses pemberian nilai telah melakukan pertimbangan-pertimbangan tertentu. Bentuk pertimbangan yang dilakukan sesuai dengan peraturan yang dituangkan dalam buku pedoman kaitannya dengan proses penilaian. Proses penilaian setiap mata kuliah harus memenuhi standar antara lain: kehadiran, tugas yang diberikan, ujian tengah semester (UTS), dan ujian akhir semester (UAS).

Akan tetapi, faktanya seringkali yang menjadi dasar mahasiswa melakukan protes hanya berdasarkan kuantitas kehadiran dan pengumpulan tugas dari dosen pengampu mata kuliah. Terlebih lagi keinginan mahasiswa memperoleh nilai minimal B seperti yang telah diuraikan sebelumnya dengan dasar hanya pada kehadiran dan tugas. Apabila dilihat dari buku pedoman pemberian nilai kepada mahasiswa, hal ini tidak sesuai karena unsur UTS dan UAS diabaikan. Kondisi demikian indikasinya tidak lain karena kurangnya pemahaman mahasiswa mengenai proses penilaian yang dilakukan oleh dosen pengampu mata kuliah sesuai buku pedoman akademik dilingkungan internal kampus.

\section{METODOLOGI PENELITIAN}

Penelitian ini mengambil lokasi di kampus IKIP PGRI Pontianak, dengan subyek penelitian mahasiswa semester VI kelas A. Pagi Prodi Pendidikan Geografi. Metode penelitian dalam upaya memperoleh data dengan menggunakan metode deskriptif. Menurut Nawawi (2015: 67) metode deskriptif dapat diartikan sebagai prosedur pemecahan masalah yang diselidiki dengan menggambarkan keadaan sebyek/obyek penelitian (seseorang, lembaga, masyarakat dan lain-lain) pada saat sekarang berdasarkan fakta-fakta yang tampak, atau sebagaimana adanya. Usaha mendeskripsikan fakta-fakta itu pada tahap permulaan tertuju pada usaha mengemukakan gejala-gejala secara lengkap didalam aspek yang diselidiki, agar jelas keadaan atau kondisinya.

Oleh karena itu pada tahap ini metode deskriptif tidak lebih daripada penelitian yang 
bersifat penemuan fakta-fakta seadanya (fact finding). Penemuan gejala-gejala itu berarti juga tidak sekedar menunjukkan distribusinya, akan tetapi termasuk usaha mengemukakan hubunganhubungannya satu dengan yang lain di dalam aspek-aspek yang diselidiki itu. Pada tahap berikutnya metode ini harus diberi bobot yang lebih tinggi, karena sulit untuk dibantah bahwa hasil penelitian yang sekedar mendeskripsikan fakta-fakta tidak banyak artinya. Untuk itu pemikiran di dalam metode ini perlu dikembangkan dengan memberikan penafsiran yang adequat terhadap fakta-fakta yang ditemukan. Dengan kata lain metode ini tidak terbatas sampai pada pengumpulan dan menyusun data, tetapi meliputi juga analisa dan interpretasi tentang arti data itu.

Bentuk penelitian yang digunakan adalah studi korelasi dalam rangka mengetahui hubungan kehadiran dan penyelesaian tugas terhadap nilai akhir mahasiswa. Seperti halnya yang diungkapkan Sukardi (2003: 166) penelitian korelasi adalah suatu penelitian yang melibatkan tindakan pengumpulan data guna menentukan, apakah ada hubungan dan tingkat hubungan antara dua variabel atau lebih. Adanya hubungan dan tingkat variabel ini penting, karena dengan mengetahui tingkat hubungan yang ada, peneliti akan dapat mengembangkannya sesuai tujuan penelitian.

Teknik pengumpulan data yang digunakan dalam penelitian adalah observasi langsung mengenai kehadiran mahasiswa mengikuti perkuliahan praktek pemetaan, sedangkan teknik dokumentasi guna memperoleh data penyelesaian tugas dan nilai akhir mahasiswa.

Analisa kehadiran mahasiswa diperoleh dari hasil observasi langsung setiap mengikuti kuliah. Hasil perhitungan kehadiran dan penyelesaian tugas mahasiswa melalui proses skoring dari lembar observasi yang selanjutnya disesuaikan dengan kriteria. Nilai akhir diperoleh dari hasil dokumentasi pengampu mata kuliah dari proses skoring sesuai tingkatan evaluasi total laporan praktikum mahasiswa.

\section{HASIL dan PEMBAHASAN}

\section{Hasil Penelitian}

Pada tahapan ini merupakan tindak lanjut dari hasil pengumpulan data/informasi mengenai kehadiran, penyelesaian tugas dan nilai akhir mahasiswa. Data yang telah dikumpulkan selanjutnya dilakukan analisa dalam rangka menjawab permasalahan yang telah dirumuskan. Lebih lanjut mengenai data kehadiran mahasiswa dalam mengikuti proses perkuliahan pada mata kuliah kartografi/praktek pemetaan dapat disajikan pada tabel 1 berikut.

Tabel 1. Data Kehadiran Mahasiswa Kelas AP Pada Mata Kuliah Kartografi/Praktik Pemetaan Prodi P. Geografi

\begin{tabular}{ccccc}
\hline No & Variabel & $\begin{array}{c}\text { Skor } \\
\text { Mentah }\end{array}$ & $\begin{array}{c}\text { Skor } \\
\text { Maksi- } \\
\text { mum }\end{array}$ & $\begin{array}{c}\text { Nilai } \\
\text { Persentase } \\
\text { (NP/\%) }\end{array}$ \\
\hline 1 & Kehadiran & 197 & 216 & 91,20 \\
\hline
\end{tabular}

Sumber: Analisis Data Primer 2017

Berdasarkan tabel 1 menunjukkan nilai persentase variabel kehadiran mahasiswa kelas A. Pagi Prodi Pendidikan Geografi yang mengambil mata kuliah kartografi/praktik pemetaan. Nilai persentase tersebut diperoleh dari hasil pencatatan yang dilakukan pengampu mata kuliah setiap pertemuan dalam jangka waktu 1 semester. Hasil proses rekapitulasi kehadiran selanjutnya dilakukan proses penskoran yang telah ditentukan sebelumnya dalam upaya mengetahui persentase keterlibatan mahasiswa secara langsung selama 1 semester. Nilai persentase dari hasil perhitungan melalui formula yang ditentukan diperoleh angka 91.20\% yang dapat dikategorikan sangat tinggi. Perolehan nilai persentase yang diperoleh tidak terlepas dari proses kerjasama antara pengampu mata kuliah dengan mahasiswa. Pengampu mata kuliah pada awal perkuliahan senantiasa memaparkan tentang mata kuliah kartografi/praktik pemetaan mencakup: perangkat pembelajaran, tujuan, alat dan bahan praktikum, teknis pelaksanaan, dan penyusunan laporan praktikum. Hal ini dilakukan dalam upaya untuk menumbuhkan kesadaran terhadap mahasiswa selama mengikuti tahapan perkuliahan guna mencapai tujuan yang telah dirumuskan 
sebelumnya. Bentuk perlakuan yang diberikan pengampu mata kuliah mulai dari awal sampai akhir perkuliahan memberikan dampak yang positif.

Fakta menunjukkan bahwasanya kehadiran mahasiswa sudah mencapai target yang diharapkan. Pada dasarnya tahapan yang dilakukan mahasiswa dalam mengikuti setiap perkuliahan/ tiap-tiap pertemuan secara perlahan mengindikasikan ada kebutuhan yang diperlukan berkenaan dengan pemahaman setiap materi yang disampaikan pengampu mata kuliah. Tahap awal mahasiswa mengikuti proses perkuliahan dapat dikatakan tidak berbeda dengan mata kuliah lain yang notabene bukan praktikum. Secara perlahan dorongan pengampu mata kuliah melalui komunikasi secara intensif terhadap mahasiswa, faktanya mampu merubah kebiasaan ketergantungan dengan rekan sejawat mulai dapat diminimalkan.

Hal ini mendorong mahasiswa dapat bertanggung jawab terhadap dirinya sendiri berkenaan dengan kebutuhan pengetahuan mengenai mata kuliah kartografi seperti yang telah disampaikan pada tiap-tiap pertemuan. Untuk dapat menyajikan laporan praktikum mata kuliah ini masing-masing mahasiswa sudah ditekankan untuk berperan aktif melakukan setiap tahapan yang diberikan pengampu mata kuliah. Karena pada intinya setiap materi/pokok bahasan yang harus dilaporkan tidak mungkin bisa direalisasikan apabila mahasiswa tidak hadir secara langsung dalam proses perkuliahan. Lebih lanjut setiap pokok bahasan yang diberikan kepada mahasiswa sifatnya berkelanjutan/berkaitan antara satu dengan lainnya, sehingga secara tidak langsung mendorong untuk senantiasa hadir dalam perkuliahan.

Kehadiran mahasiswa kelas A.Pagi yang mengikuti mata kuliah kartografi secara umum sudah mencapai standar minimal yang diharapkan. Ini bukan berarti kehadiran mahasiswa tersebut hanya sekedar memenuhi tugas sebagai bentuk tagihan perkuliahan sebagai salah satu item penilaian. Justru disisi lain mahasiswa (khususnya kelas A.Pagi) mengikuti setiap tahapan yang diberikan pengampu mata kuliah pada masing- masing pokok bahasan dengan harapan dapat memperoleh pengalaman baru selama praktikum. Orientasi nilai akhir dalam mengikuti proses perkuliahan melalui komunikasi dengan mahasiswa secara intensif terus dilakukan agar dapat menumbuhkan kesadaran bahwasannya sekecil apapun bentuk tindakan yang dilakukan dalam proses perkuliahan dapat menjadi pengalaman tersendiri bagi mahasiswa. Hal ini terbukti dapat menumbuhkan rasa ingin tahu yang cukup kuat bagi mahasiswa untuk mengajukan pertanyaan sekiranya ada sesuatu yang kurang dipahami. Bahkan ada juga yang memiliki keberanian mengajukan pendapat yang berbeda jika tidak sesuai dengan pemahaman yang didapatkan. Bentuk sikap seperti inilah yang diharapkan dapat terus dikembangkan tentunya dengan kreativitas pengampu mata kuliah dalam proses penyampaian materi sesuai rancangan yang telah disusun. Sasaran yang ingin dicapai tidak lain guna meningkatkan kesadaran mahasiswa mengikuti mata kuliah tanpa ada unsur paksaan atau tekanan dan justru menjadi sebuah kebutuhan yang harus dipenuhi.

Sudut pandang mahasiswa mengenai faktor kehadiran dalam proses perkuliahan yang perlu diluruskan/dibenahi, karena mereka beranggapan yang terpenting hadir dikelas itu sudah memenuhi salah satu item penilaian. Aktivitas yang dilakukan dikelas sekedar memenuhi kehadiran mengikuti proses perkuliahan sesuai mata kuliah yang diikuti tanpa mengedepankan tanggung jawab sebagai mahasiswa. Seharusnya kehadiran dikelas diikuti dengan aktivitas perkuliahan dalam upaya memperoleh pengetahuan dan pengalaman guna dikembangkan lebih lanjut, sehingga proses tersebut akan terus melekat dibenak masingmasing mahasiswa. Minimal mahasiswa menyadari arti pentingnya suatu proses dalam rangka menyampai tujuan tertentu yang ingin dicapai (khususnya mata kuliah kartografi/praktik pemetaan) perlu waktu yang cukup panjang. Pola pembelajaran seperti yang telah dipaparkan harus lebih ditingkatkan, sehingga tumbuh kesadaran dan rasa tanggung jawab terhadap apa yang dilakukan khususnya dalam proses perkuliahan dari tahap awal sampai akhir. Kondisi tersebut akan berdampak pada terbentuknya budaya/iklim 
perkuliahan yang kondusif tidak hanya pada mata kuliah teoritis tetapi juga praktikum.

Rasa tanggung jawab tinggi yang tumbuh pada diri mahasiswa menjadi stimulus positif dalam melaksanakan setiap tahapan proses kuliah dari awal sampai akhir. Begitu juga halnya dalam penyusunan laporan praktikum sebagai alat ukur untuk mengetahui sampai sejauh mana pemahaman mahasiswa dalam menyerap materi yang disampaikan. Hasil penyusunan laporan/tugas mahasiswa dapat disajikan pada tabel 2 berikut.

Tabel 2. Data Penyelesaian Tugas Kelas AP Pada Mata Kuliah Kartografi/Praktik Pemetaan Prodi P. Geografi

\begin{tabular}{lcccc}
\hline No & Variabel & $\begin{array}{c}\text { Skor } \\
\text { Mentah }\end{array}$ & $\begin{array}{c}\text { Skor } \\
\text { Maksi- } \\
\text { mum }\end{array}$ & $\begin{array}{c}\text { Nilai } \\
\text { Persentase } \\
\text { (NP/\%) }\end{array}$ \\
\hline $1 \quad \begin{array}{l}\text { Penyelesaian } \\
\text { Tugas }\end{array}$ & 170 & 216 & 78,70 \\
\hline \multicolumn{2}{l}{ Sumber: Analisis Data Primer 2017}
\end{tabular}

Berdasarkan tabel 2 menunjukkan rekapitulasi perhitungan hasil skoring data penyelesaian tugas praktikum mahasiswa kelas AP. Angka persentase yang diperoleh mencapai 78,70 , sesuai dengan kriteria termasuk dalam kategori sangat tinggi. Perolehan skor persentase tidak terlepas dari kerjasama yang dilakukan antara mahasiswa dengan pengampu mata kuliah melalui komunikasi pada setiap pertemuan. Penyampaian materi/pokok bahasan senantiasa mengedepankan proses bukan semata-mata hasil akhir yang justru melemahkan aktivitas dan pengembangan pola pikir mahasiswa. Langkah nyata yang dilakukan pengampu mata kuliah setiap penyampaian materi tidak terlepas dari alat peraga berupa peta dan media pendukung lainnya. Seperti halnya pemanfaatan peta Rupa Bumi Digital Indonesia (RBI) khusus wilayah Kalimantan Barat yang dilengkapi dengan data statistik pendukung sesuai wilayah yang menjadi objek kajian praktikum. Metode ini dilakukan sebagai stimulus guna menarik perhatian mahasiswa terhadap sesuatu yang belum pernah diketahui sebelumnya. Ketertarikan terhadap sesuatu tersebut sebagai modal awal untuk memotivasi mahasiswa lebih aktif dan kreatif lagi memperoleh pengetahuan dan pengalaman baru terhadap mata kuliah yang diikuti.
Faktanya mahasiswa mampu memenuhi tanggung jawab dalam proses penyusunan dan penyelesaian laporan yang diberikan pengampu mata kuliah selama satu semester. Laporan yang telah disusun sifatnya saling berkaitan satu dengan lainnya, mulai dari pemahaman dasar pemetaan sampai pada penyusunan peta tematik. Seperti yang telah dipaparkan sebelumnya bahwa orientasi laporan difokuskan ditekankan pada proses bukan hasil akhir. Jadi, tiap-tiap mahasiswa diberikan keleluasaan dalam mengembangkan materi yang disusun dalam bentuk laporan dan tentunya tetap memperhatikan kaidah-kaidah kartografisnya. Penyusunan laporan yang telah dilakukan mahasiswa pada dasarnya sudah mencapai target ketercapaian yang telah direncanakan diawal perkuliahan. Namun tidak bisa dipungkiri dengan perbedaan karakteristik mahasiswa tetap saja dijumpai ketidaklengkapan penyelesaian laporan. Berdasarkan hasil perhitungan masih sekitar $21,30 \%$ dari total mahasiswa yang belum menyelesaikan laporan secara maksimal. Berbagai macam kendala/hambatan yang dialami mahasiswa seperti halnya kesulitan memperoleh data statistik, keterbatasan jumlah peta RBI, tugas dari mata kuliah lain dalam waktu bersamaan, kurang memahami materi yang telah disampaikan, dan bahkan semangat menyelesaikan laporan yang cenderung tidak maksimal.

Hambatan/kendala tersebut tidak bisa dihindarkan ataupun diabaikan begitu saja oleh pengampu mata kuliah. Justru ini menjadi motivasi besar untuk bahan evaluasi dan dasar perbaikan proses pelaksanaan praktikum selanjutnya. Permasalahan tersebut bukan berarti menjadi tanggung jawab pengampu mata kuliah, tetapi juga pimpinan program studi melalui pengelola laboratorium yang menjadi pelaksana program praktikum. Perlu kiranya komunikasi dan koordinasi secara intensif seluruh komponen yang terlibat dalam pelaksanaan program tersebut mulai dari perencanaan, pelaksanaan dan evaluasi. Hal ini dilakukan sebagai upaya pelaksanaan program yang berkualitas untuk mencapai tujuan praktikum secara maksimal. Sekali lagi bukan hasil akhir berupa nilai yang dikedepankan, melainkan proses pelaksanaan praktikum oleh mahasiswa, sehingga menjadi budaya akademik berkelanjutan tidak 
hanya pada mata kuliah praktikum saja. Pada intinya proses yang dilakukan secara maksimal akan berbanding lurus dengan hasil akhir dalam bentuk nilai sebagai penghargaan bagi mahasiswa. Nilai akhir mata kuliah praktikum yang diperoleh mahasiswa didasarkan pada proses penyusunan laporan tahap dasar sampai lanjut. Mulai dari tahap dasar pengenalan peta sampai penyusunan informasi keruangan tematik sesuai objek wilayah kajian. Untuk lebih jelasnya mengenai nilai akhir mahasiswa yang mengikuti mata kuliah praktikum dapat disajikan pada tabel 3 berikut.

Tabel 3. Data Hasil Rekapitulasi Nilai Akhir Mata Kuliah Kartografi/Praktik Pemetaan Kelas A.Pagi

\begin{tabular}{llccc}
\hline No & Variabel & $\begin{array}{c}\text { Skor } \\
\text { Mentah }\end{array}$ & $\begin{array}{c}\text { Skor } \\
\text { Maksimum }\end{array}$ & $\begin{array}{c}\text { Nilai } \\
\text { Persentase } \\
\text { (NP/\%) }\end{array}$ \\
\hline 1 & $\begin{array}{l}\text { Nilai } \\
\text { Akhir }\end{array}$ & 3426,75 & 5400 & 63,46 \\
\hline
\end{tabular}

Sumber: Analisis Data Primer 2017

Tabel 1.3 menunjukkan hasil perolehan persentase atau rata-rata mengenai nilai akhir mahasiswa yang mengikuti mata kuliah praktikum hanya mencapai angka 63,46. Masih terdapat sejumlah mahasiswa kurang maksimal dalam pelaksanaan kegiatan praktikum, sehingga perolehan nilai tidak sesuai harapan. Seperti yang telah dipaparkan pada analisa sebelumnya bahwa banyak kendala/hambatan yang dialami oleh mahasiswa mengenai lemahnya pemahaman materi sampai proses penyusunan laporan praktikum. Ditinjau dari segi perolehan nilai sudah mencapai angka $77,78 \%$ mahasiswa yang melaksanakan kegiatan praktikum dengan baik dari tahap awal sampai akhir perkuliahan. Ratarata perolehan nilai mahasiswa dengan jumlah tersebut mencapai angka diatas 70 atau termasuk kategori baik. Hasil yang diperoleh berbanding lurus antara faktor kehadiran, penyelesaian laporan dengan nilai akhir mahasiswa. Nilai tersebut sebagai salah satu indikator untuk mengukur sampai sejauh mana pemahaman mahasiswa terhadap materi yang telah disampaikan sebelumnya.

Evaluasi terhadap mahasiswa dilakukan pada akhir penyusunan laporan ditiap-tiap pokok bahasan yang telah disampaikan pengampu mata kuliah. Hal ini dilakukan dalam upaya mengetahui secara detail mengenai kelemahan mahasiswa memahami pokok bahasan mulai dari tingkat dasar sampai lanjutan. Sebagai contoh hasil evaluasi pada pokok bahasan pertama dijadikan dasar pengampu mata kuliah guna penyampaian materi berikutnya, sehingga akan diketahui permasalahan yang terjadi secara komprehensif. Penanganan permasalahan tersebut sebagai upaya memperbaiki proses perkuliahan serta peningkatan nilai akhir mahasiswa. Penilaian yang dilakukan pengampu mata kuliah tidak semata-mata hanya melihat pada hasil akhir penyusunan laporan mahasiswa. Akan tetapi, rekam jejak/proses yang dilaksanakan oleh mahasiswa mulai dari merima materi sampai penyusunan laporan menjadi bahan pertimbangan bahkan dasar untuk memberikan nilai akhir bagi mahasiswa. Strategi tersebut dilakukan dalam rangka untuk menumbuhkan rasa tanggung jawab mahasiswa terhadap mata kuliah yang diikuti. Mulai dari kesadaran tentang kebutuhan ilmu pengetahuan dan memperoleh pengalaman selama mengikuti perkuliahan bahkan menempuh pendidikan strata 1 (sarjana).

Seperti yang telah dipaparkan sebelumnya mengenai kehadiran, penyelesaian tugas/laporan dan nilai akhir selanjutnya akan dibahas lebih detail mengenai korelasi masing-masing variabel tersebut. Untuk mengetahui seberapa besar hubungan antara kehadiran dan nilai akhir mahasiswa dapat disajikan pada tabel 4 berikut.

Tabel 4. Nilai Koefisien Korelasi Kehadiran Dengan Nilai Akhir Mahasiswa Kelas A.Pagi

\begin{tabular}{ccccc}
\hline No & Variabel & $\sum \mathbf{X 1}$ & $\sum \mathbf{Y}$ & $\begin{array}{c}\text { Koefisien } \\
\text { Korelasi } \\
(\mathbf{r})\end{array}$ \\
\hline \multirow{2}{*}{$\begin{array}{l}\text { Korelasi } \\
\text { Kehadiran \& } \\
\text { Penyelesaian } \\
\text { Tugas }\end{array}$} & 197 & 162 & 0,402996 \\
\hline
\end{tabular}

Sumber: Analisis Data Primer 2017

Berdasarkan hasil perhitungan melalui product moment diperoleh nilai koefisien korelasi sebesar 0,402996. Nilai $r$ tersebut termasuk dalam kategori hubungan yang lemah atau rendah antara kehadiran dengan nilai akhir pelaporan praktikum. 
Nilai koefisien korelasi dari hasil perhitungan sejalan dengan pemaparan pada poin pertama mengenai kehadiran mahasiswa mengikuti proses perkuliahan. Mahasiswa semester 6 secara umum dan khususnya kelas A.Pagi dalam setiap tahapan kuliah belum berjalan secara maksimal. Kehadiran mahasiswa dikelas tidak diimbangi aktivitas pembelajaran dalam upaya memperoleh pengetahuan dan pemahaman mengenai tiap-tiap pokok bahasan. Rata-rata mahasiswa sekedar memenuhi rutinitas dan target kehadiran sebagai salah satu item penilaian. Aktivitas perkuliahan yang seharusnya sebagai suatu proses memperoleh pemahaman materi dan pengalaman disetiap tahapan tidak bisa berjalan secara maksimal. Dampak lanjutan dari kondisi demikian tidak lain pada kualitas pelaporan praktikum yang seharusnya dapat dikembangkan oleh mahasiswa justru berbanding terbalik. Ketergantungan terhadap rekan sejawat dalam proses penyusunan laporan tidak bisa dihindarkan. Dalam proses penyusunan laporan praktikum diperlukan pemahaman disetiap tahapan penyampaian materi oleh pengampu mata kuliah melalui aktivitas pembelajaran disetiap pertemuan. Pada intinya kehadiran tidak bisa dijadikan dasar mahasiswa dapat menguasai pokok bahasan tanpa didukung aktivitas belajar disetiap tahapan yang disampaikan oleh pengampu mata kuliah.

Kehadiran mahasiswa merupakan tahap awal yang perlu dilakukan mahasiswa dengan penuh kesadaran dan tentunya didukung aktivitas belajar secara maksimal dalam memahami materi yang disampaikan pengampu mata kuliah. Harapannya melalui pemahaman mata kuliah secara maksimal tentunya mahasiswa tidak mengalami kesulitan dalam proses penyusunan laporan khususnya pada kegiatan praktikum kartografi/praktek pemetaan. Berikut ini disajikan tabel 5 mengenai korelasi antara penyusunan laporan dengan nilai akhir mahasiswa.

Tabel 5. Nilai Koefisien Korelasi Penyusunan Laporan Dengan Nilai Akhir Mahasiswa Kelas A.Pagi

\begin{tabular}{ccccc}
\hline No & Variabel & $\sum \mathbf{X 2}$ & $\sum \mathbf{Y}$ & $\begin{array}{c}\text { Koefisien } \\
\text { Korelasi } \\
(\mathbf{r})\end{array}$ \\
\hline 1 & Korelasi & 170 & 162 & 0,965247 \\
\hline
\end{tabular}

Penyusunan

Laporan \&

Nilai Akhir

Berdasarkan hasil perhitungan melalui product moment diperoleh nilai koefisien korelasi sebesar 0,965247. Nilai $r$ tersebut termasuk dalam kategori hubungan yang sangat tinggi antara penyusunan laporan dengan nilai akhir mata kuliah praktikum. Nilai koefisien korelasi dari hasil perhitungan sejalan dengan pemaparan pada poin kedua mengenai penyusunan laporan mahasiswa mengikuti proses perkuliahan. Mahasiswa semester 6 secara umum dan khususnya kelas A.Pagi dalam setiap tahapan penyusunan laporan sudah mencapai skor persentase sebesar 78,70. Jika ditinjau dari segi perolehan skor persentase tersebut menunjukkan bahwasannya belum semua mahasiswa mampu menyelesaikan laporan praktikum secara maksimal. Mahasiswa sebagian mengalami hambatan/kendala seperti yang telah dipaparkan pada analisa sebelumnya berkenaan dengan penyusunan laporan praktikum mata kuliah kartografi/praktek pemetaan. Data menunjukkan bahwasannya hasil penyusunan laporan sudah mampu memenuhi standar minimal dari segi jumlah mahasiswa yang memperoleh nilai baik. Total mahasiswa yang mengikuti kuliah praktikum sebanyak 54 orang hanya sekitar 12 orang yang memperoleh nilai dibawah 70 .

Data tersebut diperoleh dari hasil rekapitulasi pelaporan yang disusun mahasiswa mulai dari tahap dasar sampai lanjutan (penyusunan peta tematik sesuai kaidah kartografis). Masing-masing laporan memiliki skor nilai yang berbeda tergantung penyajian infomasi yang dilakukan mahasiswa sesuai arahan dari pengampu mata kuliah. Penekanan perolehan nilai akhir terletak pada proses dalam artian bukan hasil akhir yang telah disampaikan berupa laporan. Akan tetapi, langkah-langkah penyusunan laporan praktikum dari tahap penyajian informasi sampai pada analisa mengenai objek kajian diwilayah tertentu. Strategi ini dilakukan pengampu mata kuliah dalam rangka menumbuhkan rasa tanggung jawab yang tinggi terhadap proses penyusunan laporan secara komprehensif. Pada intinya semua dilakukan 
dalam upaya untuk merubah pola pikir mahasiswa yang berorientasi proses bukan hasil akhir berupa nilai mata kuliah semata.

\section{SIMPULAN}

Berdasarkan hasil analisa mengenai korelasi antara faktor kehadiran, penyelesaian tugas dengan nilai akhir mahasiswa dikelas A.Pagi Prodi Pendidikan Geografi, maka dapat ditarik kesimpulan sebagai berikut:

1. Kehadiran mahasiswa Pendidikan Geografi pada mata kuliah kartografi/praktek pemetaan semester VI kelas A.Pagi tahun ajaran 2016/2017 termasuk kategori sangat baik.

2. Penyelesaian tugas/nilai akhirmahasiswa Pendidikan Geografi pada mata kuliah kartografi/praktek pemetaan semester VI kelas A.Pagi tahun ajaran 2016/2017 termasuk kategori cukup baik.

3. Korelasi kehadiran dengan penyelesaian tugas/nilai akhir mahasiswa Pendidikan Geografi pada mata kuliah kartografi/praktek pemetaan semester VI kelas A.Pagi tahun ajaran 2016/2017 termasuk lemah.
4. Korelasi penyelesaian tugas dengan nilai akhir mahasiswa Pendidikan Geografi pada mata kuliah kartogrfi/praktek pemetaan semester VI kelas A.Pagi tahun ajaran 2016/2017 termasuk sangat tinggi.

\section{DAFTAR PUSTAKA}

Nawawi, Hadari, 2015. Metode Penelitian Bidang Sosial. Yogyakarta: Gadjah Mada University Press.

Nugroho, 2013. Strategi Pembelajaran Geografi. Yogyakarta: Ombak.

Sudjana Nana \& Rivai Ahmad, (2013). Media Pengajaran. Bandung: PT. Sinar Baru Algesindo.

Suharyono, 1991. Strategi Belajar Mengajar. Semarang: IKIP Semarang Press.

Sukardi, 2003. Metodologi Penelitian Pendidikan. Jakarta: PT. Bumi Aksara.

Sumarmi, 2012. Model-model Pembelajaran Geografi. Yogyakarta: Aditya Media

Publishing. 